The Impact of Audit Committee on Earnings Management: The Relevance of Malaysian Code of Corporate Governance 2007

Noor Suharniza Ahmad Ghazali, Mohd Taufik Mohd Suffian, Mohd Shatari Abd Ghafar

To Link this Article: http://dx.doi.org/10.6007/IJARBSS/v11-i8/10657

DOI:10.6007/IJARBSS/v11-i8/10657

Received: 08 June 2021, Revised: 13 July 2021, Accepted: 28 July 2021

Published Online: 22 August 2021

In-Text Citation: (Ghazali et al., 2021)

To Cite this Article: Ghazali, N. S. A., Suffian, M. T. M., \& Ghafar, M. S. A. (2021). The Impact of Audit

Committee on Earnings Management: The Relevance of Malaysian Code of Corporate Governance 2007. International Journal of Academic Research in Business and Social Sciences, 11(8), 1179-1184.

Copyright: @ 2021 The Author(s)

Published by Human Resource Management Academic Research Society (www.hrmars.com)

This article is published under the Creative Commons Attribution (CC BY 4.0) license. Anyone may reproduce, distribute, translate and create derivative works of this article (for both commercial and non-commercial purposes), subject to full attribution to the original publication and authors. The full terms of this license may be seen at: http://creativecommons.org/licences/by/4.0/legalcode

Vol. 11, No. 8, 2021, Pg. 1179 - 1184

Full Terms \& Conditions of access and use can be found at http://hrmars.com/index.php/pages/detail/publication-ethics 


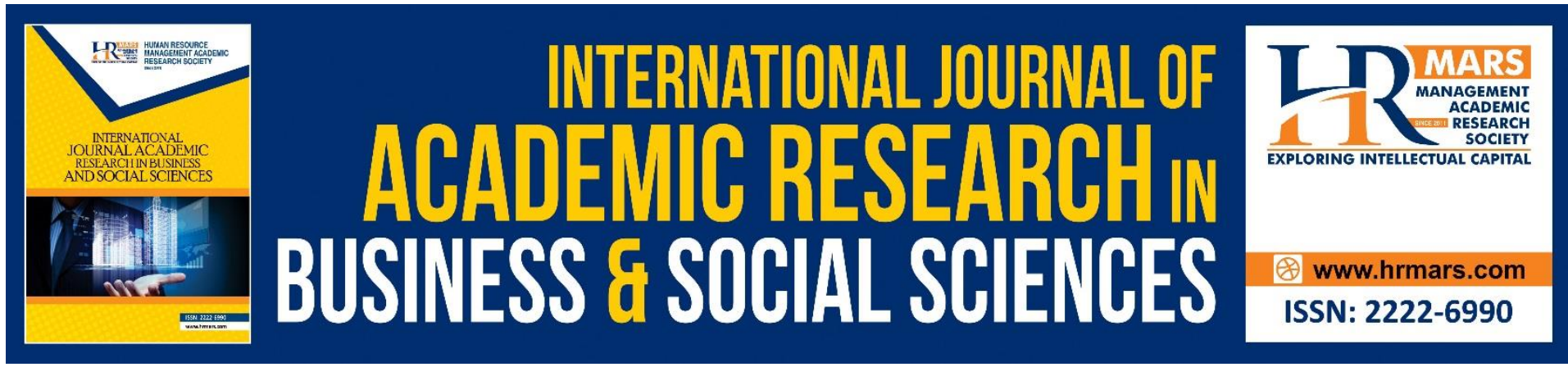

\title{
The Impact of Audit Committee on Earnings Management: The Relevance of Malaysian Code of Corporate Governance 2007
}

\author{
Noor Suharniza Ahmad Ghazali \\ Lembaga Air Perak, Jalan Pahang, 35000 Tapah, Perak, Malaysia
}

Mohd Taufik Mohd Suffian

Faculty of Accountancy, Universiti Teknologi MARA \& Accounting Research Institute (ARI), Perak Branch, Tapah Campus, 35400 Tapah Road, Perak, Malaysia

\section{Mohd Shatari Abd Ghafar}

Faculty of Accountancy, Universiti Teknologi MARA, Perak Branch, Tapah Campus, 35400

Tapah Road, Perak, Malaysia

\begin{abstract}
This study aims to determine whether there is any significant association between the audit committee effectiveness and earnings management as a proxy of earnings quality of financial reporting before and after MCCG Revised 2007. Sample data of total 96 Public Listed Company's on Bursa Malaysia in total number of year observation is 570 for six years which are three years before MCCG Revised 2007 (2004 - 2006) and three years after MCCG Revised 2007 (2009 -2011). The study finds that, there are insignificant association between audit committee effectiveness and earnings management throughout selected period before and after MCCG Revised 2007. However, from all five audit committee characteristics used as variable in this study, only one out of five characteristics of audit committee effectiveness which is higher proportion of audit committee with financial expertise is negatively and significantly associated with earnings management. This study is important as it provides additional knowledge about the impact of audit committee effectives of good corporate governance on reducing EM. Future study can include other measures of earnings quality models such as real earnings management as more accurate result can be captured, and it can be differentiated with other methods. Future research should consider other factors that may compromise the effectiveness of audit committee in performing their role on mitigating the EM activities. For examples, future research may consider the presence of inside directors and management of the company to compromise the audit committee members to perform their role effectively.
\end{abstract}

Keywords: Audit Committee Effectiveness, Earnings Management, Corporate Governance 


\section{Introduction}

The discussion on corporate governance in the world-wide countries becomes a greater concern as a result from the event of Enron Corporation collapse and the bankruptcy of WorldCom. Enron and WorldCom failure resulted from the failure of corporate governance. Furthermore, the corporate governance failures of both cases led to the massive financial reporting irregularities. In response to the Enron and WorldCom cases that related to the financial reporting failure, government, the industry, regulators and professional body emphasize rules to strengthen corporate governance. Sarbanes-Oxley Act (SOX) was enacted in July 2002 due to the recent corporate scandals related to the financial reporting failure. In Malaysia, the awareness of the importance of corporate governance come to be seen after Malaysia experienced severe difficulties due to the Asian financial crisis in second half of 1997. The Asian financial crisis was triggered in south-eastern Asia, starting in country of Thailand. The crisis was spread to the other East Asian countries including Malaysia. Researchers of prior study stated that, poor corporate governance mechanisms Mitton (2002) and financial reporting Tadesse (2006) has been a strong significant factor on business corporation performance during the East Asian financial crisis of 1997-1998. Other study reveals that corporate governance mechanisms give a significant impact to the financial reporting process and it will impair management decision making through earning management (EM) practices (Klai and Omri, 2011).

The credibility and quality of audit committee seem decreased. This will contribute to the issue of EM activities (Alakdai and Hanefah, 2012). EM activities are done by manipulating the accounting standard. As a result, the reliability of the financial statement decreases because of the financial reporting will communicate the wrong information for the users. As stated by Rahman and Ali (2006) where EM will give a negative impact to the financial reporting and fair view of the accounting information. The financial reporting manipulation cast a doubt on the role played by audit committees in protecting the credibility of the financial statement. Good corporate governance should increase the board and audit committee effectiveness and responsibility to oversight financial reporting and able to reduce the probability of EM and reduce the likelihood of financial statement fraud (Beasley, 1996; Dechow, Sloan and Sweeney, 1996). It shows that there needs one audit committee characteristics effectiveness to oversight the management to ensure they are providing high accounting reporting quality which can detect any misstatement in the financial statement prepared by the management (Beasley, 1996; Dechow et al., 1996). Therefore, considering the audit committee effectiveness give positive impact to the EM activities, it is considered important to investigate audit committee effectiveness and EM for Malaysian firms.

In recent years, there have been many fraud cases happened which has led to the EM activities. It is no surprise that management of the company has a vital interest in how they report financial statement. Many boards of directors face high pressure to maintain the good financial reporting statement. However, the most concern here is regarding to audit committee. There is an argument that how far the audit committee is responsible to followup financial matters in the company and assist the board in making financial report? So, it will provide the opportunity for the perpetrators to manipulate the EM. EM is usually undertaken by the management team rather than the audit committee members. This argument is supported by Hussain Alakdai and Hanefah (2012) who also argues that investors and shareholders should be aware of management ability to alter accounting report for opportunistic purposes. 
There is a need of audit committee effectiveness because it is important in order to mitigate the EM activities among the manager of the companies. Any financial information disclosed by management should be more scrutinized in order to avoid EM practices in reporting process (Jamil and Nelson, 2011). However, the question is whether the audit committee will act effectively to mitigate the EM activities among the company management. In additional regulators have questioned the audit committee's effectiveness in ensuring that financial statement is from material misstatement and are without EM occurred. Malaysia government has introduced MCCG Revised (2007) to restrain the problem occur regarding EM.

MCCG Revised (2007) is to strengthen the quality of the board and audit committee and ensuring the board and audit committee discharging their roles and responsibility effectively. Therefore, it is expected to lower the EM activities and at the same time it will increase the quality of financial reporting. The efforts between government, the industry, regulator and professional body especially regarding to audit committee effectiveness leads to more research needed to be done in this area to confirm whether the audit committee characteristics stipulated in MCCG Revised (2007) give any impact on company in Malaysia in producing a financial reporting free from material misstatement which is without EM occurred.

Since, there are relatively few research conducted in the area of effectiveness of audit committee on financial reporting quality among Malaysian firms, more research needs to be done especially in Malaysia to improve the reliability of the previous result and this study also will broaden the scope by providing evidence of the relationship between audit committee characteristic and financial reporting quality. This current study examines the effectiveness of audit committee characteristics on EM in a period prior to and after the MCCG Revised (2007).

\section{Literature Review \& Hypotheses Development Audit Committee Independence}

Referred to the Bursa Malaysia Listing Requirements (BMLR), independent means a director who is independent of management and free from any business or other relationship or having no shares in the company and having no relationship with any executive director, officer or major shareholder which could interfere with the exercise of independent judgment or the ability to act in the best interests of an applicant or a listed issuer. Thus, for Malaysian listed company, audit committee independence increases the effectiveness of audit committee which is consistent with MCCG (2000), MCCG Revised (2007) and BMLR. The independent non-executive directors help to strengthen the role of audit committee. As the independence of the audit committee increases it is expected to help company to enhance the monitoring function on behalf of shareholders (Jamil and Nelson, 2011). This study also reports that the EM is influence by the audit committee independence. A prior research suggests that audit committee independence is positively related to effective oversight of financial reporting process (Bronson, Carcello, Hollingsworth, and Neal, 2009). Beasley, Carcelle, and Hermanson (1999); Bedard et al (2004); Klein (2002) find that the audit committee independent helps in effective monitoring of management and significantly reduced the likelihood of financial misstatement. These results suggest that more independent audit committee will contribute to be more effective in monitoring process. Other prior research found that audit committee independence is significantly associated with EM (Davidson et al., 2005; Vafeas, 2005; Klein, 2002). In the Malaysian context, Saleh et 
al. (2007) provide evidence that the fully independent audit committee reduces EM practices. Therefore, the first hypothesis is:

H1: Firms with a higher number of independent audit committee members are negatively associated with EM.

\section{Audit Committee Size}

The size of audit committee is referred to as the number among member of directors who is appointed to be members in the audit committee where the size of audit committee could be small, medium and large audit committee (Alkdai and Hanefah, 2012). The MCCG (2000); the MCCG Revised (2007) is consistent with the BMLR that the board should establish an audit committee comprising at least three members. These requirements reflect previous study which suggest that audit committee size may attribute to the audit committee effectiveness (Liu and Sun, 2010). Baxter and Cotter (2009) mentioned that the large size of an audit committee should have a positive effect on EM. Since manager aims to provide false financial position and performance for self-interest, the larger audit committee may play important role to mitigate EM (Alkdai and Hanefah, 2012). Other previous study report that audit committee size is negatively associated with EM Jamil and Nelson (2011), Al-Najjar (2011), and Yang and Krishnan (2005), which provide with more diverse skill and knowledge to enhance monitoring resources available to the committee and improve monitoring quality which can lead to reducing the earning management practice. Therefore, the second hypothesis is:

$\mathrm{H} 2$ : Firms with higher number of audit committee members are negatively associated with earning management.

\section{Audit Committee Expert}

The responsibility of audit committee is to oversee the accounting and financial reporting process as well as the audit of financial statements. Therefore, it has been argued that audit committee members are required to possess sufficient financial, accounting and auditing knowledge to effectively oversight accounting and financial reporting process (Jamil and Nelson, 2011). As mentioned by Bedard et al. (2004), financial expertise of audit committee members are important characteristics for an audit committee to effectively oversight the accounting, financial reporting and audit process. In addition, financial experts assigned to audit committee can improve the audit committee's ability to ensure high quality of financial reporting. Defond, Hann, and $\mathrm{Hu}$ (2005) and Davidson et al. (2004) find significantly positive stock price reaction when firms appoint financial expertise to their audit committee. Thus, consistence with BMLR and MCCG Revised (2007) require at least one member of the audit committee should be a member of a professional accounting body such as Malaysian Institute of Accountants (MIA) or if he is not a member of MIA, he must have at least 3 years' working experience and must be a member of one of the associations of accountants. Furthermore, as stated on MCCG Revised (2007), all members of the audit committee should be financially literate so that they will be able to effectively discharge their functions. Several studies have found that there is a negative association between the audit committee financial and accounting expertise and EM (Bedard et al., 2004; Felo et al., 2003; and Xie et al., 2003). Based on the above arguments, this study hypothesized that: 
H3: Firms with higher proportion of audit committee with financial expertise are negatively associated with EM.

\section{Audit Committee Meeting}

The frequency of audit committee meeting can help to enhance audit committee effectiveness and mitigate EM practice. McMullen and Raghunandan (1996) stated that audit committee meet regularly would increase the committee effectiveness and help to ensure the financial reporting process is functioning properly in every quarter of the year. Consistence with the MCCG Revised (2007) requires the audit committee should meet at least twice a year. The Revised Code increase the frequency of meeting to encourages a greater view of financial reporting process. There are several previous studies which argue that the firm increase the frequency of audit committee meeting due to the problems arising in internal control of the firms (Zhang et al., 2006). Abbott et al. (2000) provide evidence that the frequency of audit committee meeting is significantly and positively related to mitigate likelihood of misstatement. More frequent meetings enable the audit committee to function properly and send a signal that the committee intends to remain informed and vigilant as consequence help to improve mitigate EM practice and avoid potential problem in the future (McMullen and Raghunandan, 1996). Therefore, the fourth hypothesis is:

H4: Firms with higher frequency of audit committee meetings are negatively associated with EM.

\section{Audit Committee Tenure}

Past study mentioned that working experience play an important role in measuring job performance (Schimidt, Hunter, and Outerbrigde, 1986). Quinones et al. (1995) show that working experience had a highest correlation with job performance. It shows that working experience result from long tenure can increase job performance, have greater experience, expertise and reputation (Liu and Sun, 2010) and enhance directors' commitment to fulfil their duties (O'Reilly and Caldwell, 1981). Consistence with SET (1999) the term of service of the committee members should be definitely fixed and covers a reasonable period of 2 to 5 years to ensure continuity of the performance of work of the audit committee. Thoopsamut and Jaikengkit (2009) suggest that as experience audit committee member increase, it would allow them to develop their monitoring competencies and knowledge of the operations and as consequences increase the effectiveness to oversight EM practice. On the other hand, Liu and Sun (2010) argue that long board tenure may lead to be ineffectiveness of outside directors. The directors with an extensive length of board tenure are more likely to have a close relationship with the management and they become less effective to monitor over management (Vafeas, 2003; Yang and Krishnan, 2005; Thoopsamut and Jaikengkit, 2009). Liu and Sun (2010) find that the long tenure independent audit committee is negatively associated with EM. Thus, the fifth hypothesis is:

H5: Firms with higher average tenure of audit committee are negatively associated with EM.

\section{Agency Theory}

The theory of this study basically is concerned on the agency theory, where agency conflict arises because of the conflict of interest between the manager (agent) who has power of decision making and the shareholder (principal). The conflict of agency arises when the 
agent who is in control the firm is more interested in its self-interest in making profit, and in turn he may not suffer any loss in future commission, rather than creating value to the firm (Fama, 1980).

Further discussion of agency theory is extended by Jensen and Meckling (1976). They recognize that the firm serves as a nexus of contract relationship between the agent and principal. The agency conflict arises when the shareholder (principal) hire the manager (agent) to take responsibility to perform some duties and have the authority to make decision for the firm. These relationships increase the concern on the agency conflict on conflict of interest that may arises between the agent and principal. This issue concerns on the conflict of interest between agent and principal where sometimes management may not act in the best interest of shareholders. Therefore, monitoring system should be implemented to monitor the agent activities and performance of the firm.

Agency theory is relevant to the study because it explains the function of audit committee as a monitoring mechanism to prevent conflict of interest between agent and principal, (Jamil and Nelson, 2011; Bradbury et al., 2006; Rahman and Ali, 2006). Issue of the association between agency theory, audit committee and financial reporting is discussed often by the various researchers. The corporate governance mechanism which is one of them is audit committee is expected to play significant role as a monitoring device to examine the association between corporate governance function and EM (Sivaramakrishnan, 2008).

\section{Data Collection and Sample Selection}

This study is carried out among the Malaysian companies listed on Bursa Malaysia. This study uses secondary data as the main source of information. The data relating to the audit committee independence, audit committee expert, audit committee size, audit committee meetings, audit committee tenure, firm size, leverage and return on assets are collected from company annual report and DataStream. In this study the companies were selected prior and after the MCCG Revised (2007) as to examine the impact of audit committee effectiveness on the magnitude of EM activities prior and after the Code revised 2007. Table 3.1 describes the derivation of the sample in this study. Sample data for year end 2007 and 2008 are excluded to account as information sources because they are seen as a transition period where the effect of the Code revised may take for a few years. Mohd Shatari (2012) also stated that the implementation of a new Code may take effect for several years. The public listed companies from finance sector (banks \& financial sector and insurance sector) which are excluded in the sample selection due to their financial statement's components are different from non- finance sectors. 
Table 3.1

Derivation of the Sample

\begin{tabular}{l|c|c}
\hline & No. of Firms & $\begin{array}{c}\text { No. of Firms } \\
\text { Year }\end{array}$ \\
\hline $\begin{array}{l}\text { Total no. of firms listed on Bursa Malaysia Main } \\
\text { Board as at 31 December 2011 }\end{array}$ & 822 & 4932 \\
\hline $\begin{array}{l}\text { Less: Firms with financial year-end other than 31 } \\
\text { December }\end{array}$ & 384 & 2304 \\
\hline $\begin{array}{l}\text { Less: Firms from financial, insurance and unit trust } \\
\text { sector }\end{array}$ & 50 & 2628 \\
\hline $\begin{array}{l}\text { Less: Firms with incomplete data (unavailable } \\
\text { annual report, unavailable financial data, } \\
\text { unavailable corporate governance data and de- } \\
\text { listed firms). }\end{array}$ & 388 & 2328 \\
\hline \begin{tabular}{l} 
Total final sample \\
\hline
\end{tabular} & $\mathbf{9 5}$ & 1758 \\
\hline
\end{tabular}

\section{Measurement Variables}

Various study use audit committee independence, audit committee size, audit committee meeting, audit committee expertise, audit committee diligence, audit committee tenure as a measurement of audit committee effectiveness (Jamil and Nelson, 2011; Alkdai and Hanefah, 2012; Owens-Jackson et al., 2009). On the other hand, most of the articles used discretionary accruals as a proxy for EM. Additionally (Dechow et al.,1995) examine that discretionary accruals models (Modified Jones Model) has the ability to detect low power of EM magnitudes. Dechow et al. (1995) also found that the Modified Jones (1991) Model is the most powerful in detecting earnings manipulation made by managers in exercising their discretion over revenue recognition. Only a few articles used other measurement for EM such as Sivaramakrishnan and $\mathrm{Yu}$ (2008) and Kim and Yoon (2008) total accruals, earnings persistence, Lin and Hwang (2010), Abbott et al. (2004), Beasley (1996) and Lin et al. (2009) financial restatement, and lastly Beasley (1996) and Lin and Hwang (2010) fraud. Thus, this study focuses only on discretionary accruals and excludes other proxy of EM. Meanwhile, this study focuses on audit committee independent, audit committee size, audit committee meeting, audit committee expertise, and audit committee tenure as a measurement of audit committee effectiveness. Table 3.2 describes the dependent variables and independent variables used in this study. 
Table 3.2

Variables Measurements

Variables

Operational Measures/ Description

Dependent Variable

Discretionary accruals (DACC)

Total accrual minus non-discretionary accrual.

\section{Independent Variables}

Audit Committee Independent (ACIND)

Audit Committee Expert (ACEXP)

Audit Committee Size (ACSIZE)

Audit Committee Meetings (ACMEET)

Audit Committee Tenure (ACTEN)
The proportion of independent directors on the audit committee.

The proportion of audit committee members who possess professional accounting qualification (ACCA etc.) or member of any professional accounting bodies (MIA, CPA etc.) or he must have passed examinations specified in Part I of the $1^{\text {st }}$ Schedule of the Accountants Act,1967 or he must be a member of one of the Associations specified in Part $\|$ of the $1^{\text {st }}$ Schedule of the Accountants Acts, 1967 to the total number of audit committee members.

Total number of audit committee members.

Number of audit committee meeting held during the financial reporting year.

The average tenure of the audit committee (the proportion of tenure directors on the independent audit committee).

\section{Control Variables}

Firm size (SIZE)

Log Total Asset.

Leverage (LEV)

The Ratio of liabilities to / total assets.

Return on Asset (ROA)

The ratio of net income / total assets.

\section{Research Methodology}

This study used discretionary accruals estimation as a proxy of EM. To calculate discretionary accruals, non-discretionary accruals and total accruals is estimated. Discretionary accruals are measured after total accruals minus non-discretionary accruals 
(DACC $=$ TACC - NDACC $).$ Total accrual can be calculated between the difference of earnings and cash flow from operations. This study used Modified Jones Models to measure the discretionary accruals in the following equation:

$\mathrm{TACC}_{i}, t / \mathrm{TA}_{i}, t_{-1}=\alpha_{0}+\left(\alpha_{1} 1 / \mathrm{TA}_{i}, t_{-1}\right)+\alpha_{2}\left(\Delta \mathrm{REV}_{i}, t / \mathrm{TA}_{i, t-1}-\Delta \mathrm{REC}_{i}, t / \mathrm{TA}_{i}, t_{-1}\right)+\alpha_{3}\left(\mathrm{PPE}_{i}, t / \mathrm{TA}_{i}, t_{-1}\right)+$ $\varepsilon_{i}, t$

Where:

$\varepsilon_{i}, t \quad=$ Discretionary accruals

$\triangle \mathrm{REV}_{i} \quad=$ Revenues in year $t$ less revenue in year $t-1$

$\triangle R \mathrm{C}_{i}, t \quad=$ Net receivables in year $t$ less Net receivables in year $t-1$

$\mathrm{PPE}_{i}, t \quad=$ Gross Property Plant and Equipment at the end of year $t$

$\mathrm{TA}_{i, t} t_{-1} \quad=$ Total Assets at the end of the year $t-1$

$\mathrm{TACC}_{i}, t=$ Total Accruals

The value obtained from the above regression measures non-discretionary accruals:

$\mathrm{NDACC}_{i}, t=\alpha_{0}+\left(\alpha_{1} 1 / \mathrm{TA}_{i}, t_{-1}\right)+\alpha_{2}\left(\Delta \mathrm{REV}_{i}, t / \mathrm{TA}_{i}, t_{-1}-\Delta \mathrm{REC}_{i}, t / \mathrm{TA}_{i}, t_{-1}\right)$

(2)

$$
+\alpha_{3}\left(\mathrm{PPE}_{i}, t / \mathrm{TA}_{i}, t_{-1}\right)
$$

The residual measure discretionary accruals:

$\mathrm{DACC}_{i}, t=\mathrm{TACC}_{i}, t / \mathrm{TA}_{i}, t_{-1}-\mathrm{NDACC}_{i}, t$

Where $\mathrm{NDACC}_{i}, t$ is nondiscretionary accruals for firm in year $t$ and $\mathrm{DACC}_{i}, t$ is discretionary accruals for firm $i$ in year $t$.

The regression analysis is used to investigate the impact of audit committees' effectiveness on the EM in Malaysia. Audit committee effectiveness and other control variable are modelled as independent variable. The regressions model for discretionary accruals (DACC) used in this study are as follows:

$\mathrm{DACC}=\alpha_{0}+\alpha_{1} \mathrm{ACIND}+\alpha_{2}$ ACEXP $+\alpha_{3}$ ACSIZE $+\alpha 4$ ACMEET $+\alpha 5$ ACTEN $+\alpha 6$ SIZE $+\alpha$ 7LEVERAGE $+\alpha 8 \mathrm{ROA}+\varepsilon$

(4)

\section{Data Analysis}

Prior to conducting descriptive and pooled regression correlation analysis, the test of normality was carried out first in this study. Rahman and Ali (2006) the normality of data is analysed by obtaining the skewness and kurtosis values where the data are said to be normal if the standard skewness is within \pm 1.96 and standard kurtosis of \pm 2 .

The descriptive statistic of DACC used to show the magnitude of absolute value of DACC of the companies. Descriptive statistic also used to show the statistic of mean, median, mode and standard deviation for independent variables. This study used Pearson's Correlation Coefficients approach to examine the relationship between the dependent and independent variables. For further explanation, this test is to examine to what extent both dependent and independent variables in the study are related. The test indicates whether 
there is positive or negative relationship between DACC and audit committee characteristic (independent variables).

Finally, Pooled Regression analysis is conducted to predict the outcome of the hypothesis. The regression is an analysis assessing the impact of audit committee effectiveness on EM practice in Malaysian Public Listed Companies prior and after the Revised Code (2007).

\section{Descriptive Analysis}

Table 4.1 presents the descriptive statistic results for all variables investigated in this study. The descriptive statistic is explained on the mean, maximum, minimum and standard deviation values of the dependent and independent variable used in this study. From the all 570 data observation of financial and non-financial data for the period of pre and post of MCCG Revised (2007), from years 2004 to 2006 and 2009 to 2011.

The result of descriptive statistics for dependent variable shows the mean of discretionary accruals for this study is in negative value -0.4856 whereas the minimum value is -2.037 of discretionary accruals for this study is in negative value -0.4856 whereas the minimum value is -2.037 . The result of descriptive statistic for independent variable show the mean of audit committee size is 3.52. Furthermore, the maximum value of the audit committee size was 6 whereas the minimum value is 3 . The result regarding to the minimum value of audit committee size meet the requirement of the MCCG and BMLR, where the audit committee must be composed of not fewer than 3 members. The number of audit committee members should be appropriately appointed to make sure that there are enough members to carry out responsibility to the organization effectively (MCCG, 2000).

Table 4.1

Descriptive Statistics for the Variables Audit Committee Effectiveness for the Period (2004 - 2006) and (2009 - 2011) ( $N=570)$

\begin{tabular}{lcccc}
\hline \multicolumn{1}{c}{ Variables } & Minimum & Maximum & Mean & $\begin{array}{c}\text { Std. } \\
\text { Deviation }\end{array}$ \\
\hline DACC & -2.037 & 4.173 & -.48567 & .400373 \\
ACSIZE & 3.000 & 6.000 & 3.51754 & .691811 \\
ACIND & 1.000 & 5.000 & 2.73684 & .642007 \\
ACEXP & .000 & 4.000 & 1.24211 & .553927 \\
ACMEET & .000 & 16.000 & 5.10351 & 1.474382 \\
ACTEN & 1.000 & 22.000 & 7.99595 & 4.316962 \\
FIRM SIZE & 4.760 & 8.013 & 5.98004 & .584922 \\
LEV & .032 & 1.455 & .41142 & .200878 \\
ROA & -1.222 & .525 & .04515 & .095650 \\
\hline
\end{tabular}

This table provides summary statistics for the variables employed in the study. DACC (Discretionary Accruals) = Total accrual minus non-discretionary accruals, ACSIZE (Audit Committee Size) $=$ Total number of audit committee members, ACIND ( Audit Committee Independent) $=$ The proportion of independent directors on the audit committee, ACEXP (Audit Committee Expert) $=$ The proportion of audit committee members who possess professional accounting qualification (ACCA etc.) or member of any professional accounting bodies (MIA, CPA, etc.) to the total number of audit committee members, ACMEET (Audit Committee Meetings) = Number of audit committee meetings held during the financial reporting year, ACTEN (Audit Committee Tenure) $=$ The average tenure of the audit 
committee (the proportion of tenure directors on the independent audit committee), FIRM SIZE $=$ log total asset, LEV (Leverage) $=$ the ratio of liabilities to / total assets, ROA (Return On Assets) $=$ the ratio of net income / total assets

\section{Multicollinearity Test}

Table 4.2 displayed Multicollinearity analysis to test whether all the variables used in the multiple regression analysis is violate the Multicollinearity assumption. The Multicollinearity test is not violated if the value of tolerance is higher than 0.1 and the Variance Inflation Factor (VIF) value is close to 1 . The result shows that all the value of tolerance is higher than 0.1 and all the VIF values are close to the value of 1 .

Table 4.2

Multi- Collinearity Test

\begin{tabular}{lcc}
\hline & \multicolumn{2}{c}{ Collinearity Statistics } \\
\cline { 2 - 3 } & Tolerance & VIF \\
\hline (Constant) & & \\
ACSIZE & .784 & 1.275 \\
ACIND & .734 & 1.362 \\
ACEXP & .899 & 1.112 \\
ACMEET & .818 & 1.222 \\
ACTEN & .878 & 1.138 \\
FIRM SIZE & .762 & 1.313 \\
LEV & .945 & 1.058 \\
ROA & .885 & 1.129 \\
DUMMY TRANSITION BEFORE AND AFTER CODE & .731 & 1.368 \\
REVISED & & \\
\hline
\end{tabular}

Therefore, the result of regression analysis shows that there is no Multicollinearity problem between all the variables used in this study. The highest VIF in this study is 1.362 and the lowest VIF in this study is 1.058.

\section{Correlation Analysis}

Correlation coefficient analysis reports the degree of relationship exist between two variables used in the research (Taylor, 1990). Hence, the correlation coefficient in this current study will be performed to examine the existence and strength of the linear relationships between discretionary accruals as a proxy of EM and audit committee characteristics, which include audit committee size, audit committee member that being independent, frequency of audit committee meeting and length of audit committee tenure.

Table 4.3 shows the bivariate analysis to test the correlation coefficient between one variable to another. The result shows that for discretionary accruals (DACC), only one independent variable of audit committee characteristics which is audit committee expert is significantly negatively correlation at $(r=-0.133, p<0.01)$. Other variable is not correlated with discretionary accruals. Hence, this provides the evidence that, when there is audit committee accounting expertise the tendency of EM would be decrease.

Other than audit committee expert (ACEXP), all the other independent variables are not significantly correlated with the DACC. DACC are positively associated with audit committee size (ACSIZE), audit committee independent (ACIND) and Leverage (LEV). On the 
other hand, DACC are negatively associated with audit committee meeting (ACMEET), audit committee Tenure (ACTEN). The correlation between ACMEET and FIRM SIZE are the highest correlation with the result $r=0.305$ with significant at $p<0.01$.

For ACSIZE, this variable is a significantly negatively correlated with ACIND, $(r=-0.187$, $p<0.01), A C E X P,(r=-0.224, p<0.01)$, and significantly positively correlated with ACMEET, $(r$ $=0.198, p=0.01)$, ACTEN, $(r=0.151, p<0.01)$, FIRM SIZE with log of total assets, $(r=0.273, p$ $<0.01)$ and ROA, $(r=0.125, p<0.01)$. Hence, for ACIND, this variable is significantly positively correlated with ACEXP where $(r=0.101, p<0.05)$. This result suggest that audit committees independent and audit committee financial expertise are work together to overseeing and monitoring financial reporting process and monitor managers' interest on manipulate earnings effectively.

Meanwhile for ACEXP, this variable is significantly negatively correlated with ROA, $(r$ $=0.139, p<0.01)$. Result for ACMEET shows this variable is significantly positively correlated with FIRM SIZE log of total assets, $(r=0.305, p<0.01)$, where this result is the highest correlation. ACMEET also shows a negative correlation with ROA, $(r=0.160, p<0.01)$. Lastly result for ACTEN shows this variable is significantly correlated with FIRM SIZE log of total assets, $(r=0.260, p<0.01)$.

Table 4.3

Pearson Correlations of the Variable for the Period of 2004 - 2006 and (2009 - 2011) $(N=570)$

\begin{tabular}{cccccccccc}
\hline & DACC & ACSIZ & ACIND & ACEXP & $\begin{array}{c}\text { ACMEE } \\
\text { T }\end{array}$ & ACTE & FIRM & \multirow{2}{*}{ LEV } & ROA \\
\hline DACC & 1.000 & & & & & & & & \\
ACSIZE & .009 & 1.000 & & & & & & & \\
ACIND & .040 & $-.187^{* *}$ & 1.000 & & & & & & \\
ACEXP & $-.133^{* *}$ & $-.224^{* *}$ & $.101^{*}$ & 1.000 & & & & & \\
ACMEE & -.067 & $.198^{* *}$ & -.049 & .035 & 1.000 & & & & \\
T & & & & & & & & \\
ACTEN & -.027 & $.151^{* *}$ & .078 & -.090 & -.048 & 1.000 & & & \\
FIRM & -.063 & $.273^{* *}$ & .090 & -.050 & $.305^{* *}$ & $.260^{* *}$ & 1.000 & & \\
SIZE & -.063 & & & & & & & \\
LEV & .066 & -.017 & .022 & .014 & .092 & -.010 & $.154^{* *}$ & 1.000 & \\
& & & & & & & & - & \\
ROA & -.026 & $.125^{* *}$ & .041 & $.139^{* *}$ & $-.160^{* *}$ & .089 & .064 & $.140^{*}$ & 1.000 \\
& & & & & & & & ${ }^{*}$ &
\end{tabular}

**. Correlation is significant at the 0.01 level (1-tailed).

*. Correlation is significant at the 0.05 level (1-tailed).

\section{Multiple Linear Regressions}

Multiple linear regressions would explain the linear relationship between one dependent variable and two or more independent variable. In this study, multiple linear regressions used to test the hypothesis 1 , hypothesis 2 , hypothesis 3 , hypothesis 4 and hypothesis 5. The entire five hypotheses would consider the Revised Code of MCCG 2007. Therefore, dummy variable for Revised Code 2007 used to control the regression model. The summary of the result of multiple linear regression analysis is presented in table 4.4: 
Table 4.4

Multiple Regression Analysis

\begin{tabular}{|c|c|c|c|c|c|c|}
\hline & & \multicolumn{2}{|c|}{$\begin{array}{l}\text { Unstandardized } \\
\text { Coefficients }\end{array}$} & \multirow{2}{*}{$\begin{array}{c}\text { Standardized } \\
\text { Coefficients } \\
\text { Beta }\end{array}$} & \multirow[b]{2}{*}{$\mathbf{t}$} & \multirow[b]{2}{*}{ Sig. } \\
\hline & & B & $\begin{array}{l}\text { Std. } \\
\text { Error }\end{array}$ & & & \\
\hline Indipendent & (Constant) & -.134 & .205 & & -.653 & .514 \\
\hline \multirow[t]{5}{*}{ Variables } & ACSIZE & .023 & .027 & .040 & .866 & .387 \\
\hline & ACIND & -.002 & .134 & -.001 & -.018 & .986 \\
\hline & ACEXP & -.354 & .108 & -.143 & -3.286 & .001 \\
\hline & ACMEET & -.017 & .013 & -.063 & -1.394 & .164 \\
\hline & ACTEN & -.004 & .004 & -.048 & -1.095 & .274 \\
\hline Control & FIRM SIZE & -.052 & .032 & -.075 & -1.597 & .111 \\
\hline \multirow[t]{7}{*}{ Variables } & LEV & .179 & .084 & .090 & 2.121 & .034 \\
\hline & ROA & -.012 & .183 & -.003 & -.065 & .948 \\
\hline & DUMMY & .112 & .039 & .140 & 2.897 & .004 \\
\hline & TRANSITION & & & & & \\
\hline & $\mathrm{N}$ & 570 & & & & \\
\hline & Adjusted R & .034 & & & & \\
\hline & F - value & $3.251^{* *}$ & & & & \\
\hline
\end{tabular}

The result of multiple regression indicates that there is a negative relationship with insignificant relationship between discretionary accruals and audit committee independent at 5 percent significant level. This result seems to be consistent with several literatures that investigate the association of audit committee independent on EM for Malaysian firms (e.g. Owens-Jackson, 2009; Rahman and Ali, 2006). This result is also consistent with issue raised by Lin et al. (2009) examines that audit committee members who are independent fail to play a mitigating role in EM practice.

For hypothesis 4 and hypothesis 5, the result of multiple regression found that, there is negative relationship for both audit committee meeting and audit committee tenure with discretionary accruals. However, both audit committee meeting and audit committee tenure insignificantly related to the discretionary accruals with result at $(r=1.394, p>0.05)$, and $(r=$ 1.095, $p>0.05$ ) respectively. Consistence with Jamil and Nelson, (2011) investigate on Malaysia firm, find that they are not able to find any association with the magnitude of EM on the frequency of audit committee meetings. Rahman, and Ali, (2006) also stated that there is insufficient evidence to accept the audit committee meetings which are effective to monitor in reducing EM. This result also is in consistence with Sharma, et al. (2009), Lin, et al. (2009), and Thoopsamut and Jaikengkit (2009) who find that frequency of audit committee meetings is not have a significant impact on the EM practice. Same goes to audit committee tenure where, this study find that audit committee tenure insignificantly related to the discretionary accrual. However, the result of audit committee tenure in this study is consistent with other studies such as Vafeas (2003) states that long tenure director are more likely to have a close relationship with the management and it will impair the objective of the audit committee to mitigate the EM practice occur in the firms. Vafeas (2003) also state that long tenure director is less interest in their job performance as consequence will dramatically 
impair their reputational in reducing EM practices. Therefore hypothesis 4 and hypothesis 5 is partially accepted.

For hypothesis 2, the result found a positive insignificant relationship between audit committee size and discretionary accruals as a proxy of EM. However, this result is consistent with Malaysian firm study (e.g. Jamil and Nelson, 2011; Hussain Alkdai and Hanefah, 2012; Bradbury et al., 2006) indicate that audit committee size has non-significant relationship with the discretionary accruals used as a proxy for EM. Hussain Alkdai and Hanefah (2012) also indicate that the larger the audit committee, the more EM practice in the companies. Therefore hypothesis 2 is not accepted in this study.

Hypothesis 3 found a negative significant relationship between audit committee expert and discretionary accruals at $(r=3.286, p=0.001)$ where $p<0.01$ percent significant level. This is consistent with the study of Xie et al. (2003) and Bedard et al. (2004), which found that financial expert in audit committee is associated with lower EM. It shows that audit committee act as monitoring devices (Felo et al, 2003; Agrawal et al., 2005; Xie et al., 2003) and enable them to execute their oversight duties effectively to make sure the managers do not manipulate the financial reporting statement and impair the EM (Beasley, 2000). Therefore, the hypothesis 3 is accepted in this study.

In additional regression analysis, the result also found that dummy transition of MCCG Revised (2007) is positively significantly correlated with EM at $(r=2.897, p=0.004$ where $p<$ 0.01 percent significant level. This indicates that Revised Code seems not effectively to prevent EM in this study. This is consistent with Rahman and Ali (2006) that companies comply with the MCCG may not achieve to prevent EM if the establishment of an audit committee do not pose the required responsibility.

\section{Implications of the Study}

This study provides empirical evidence of the audit committee effectiveness and EM of public listed company before and after the MCCG Revised (2007). Practically this study appears that only audit committee expertise influences the effectiveness of the audit committee on EM before and after the MCCG. This study provides management of the company, the investor, the decision maker and other user of financial information to understand that the audit committee expertise in accounting have an important role on the mitigating the EM activities in the Public Listed Company in Malaysia. This finding also gives some input for the regulator, policy makers such as Security Commission Malaysia and government to encourage the management of the public listed company to improve the role and characteristic of audit committee members especially audit committee expertise in accounting as an important medium to mitigate EM practice.

Furthermore, this study provides a good indicator to increase the commitment of the management of the company, government, policy makers, and regulators to increase the quality of the corporate governance of Malaysia, regulation. This study also makes the governance, policy makers and regulators to take initiative to make some revision to identify and improve the existing corporate governance regulations that are important in enhancing and increase the efficiency and effectiveness of the audit committee board on the public listed company. With good governance, the encouragement from the regulator and 100 percent commitment from the management of the company, audit committee members may play their role and as a result it may enhance the financial reporting process and hence, mitigate EM. 
This empirical evidence can be used as an indicator for new corporate governance regulations and for the revision of existing corporate governance systems because this study provides the best empirical result of the association between audit committee characteristics and EM on the code of corporate governance.

\section{Limitations and Recommendations of The Study}

This research has its own limitations. Firstly, this study only covered 96 numbers of Public Listed Companies from various sector in Bursa Malaysia. The number of Public Listed Company in this research is considered relatively low, hence, it cannot generate accurate result for the whole Public Listed company population.

Secondly, some of the variables used as audit committee characteristics may not be a good proxy for this study. For instance, the audit committee tenure which is one of the audit committee characteristics in this study did not take consideration of the length of the director served in the company. The audit committee tenure did not cover the possibility of the director who have longer time period served in the company which may compromise the ability of the audit committee members to serve their responsibilities in effective way.

Lastly, this research study used the longest way to gather all the data needed because the DataStream is being upgraded in the year this study initiated. The lack of knowledge and the different presentation of the new upgrade DataStream caused a difficult situation to obtain the information needed in this study. Furthermore, the way to gather the data is differs from the previous DataStream.

In future research, it is suggested to add longer sample of time period of data gathered for the pre and post period of the MCCG Revised 2007. Therefore, the result can be improved to examine the EM activities. Research with longer time frame of period also may be able to capture the effect of sound corporate governance on the audit committee effectiveness to reduce the EM activities.

In addition, it is suggested that future research should include other measures of earnings quality models. By using the other method to measure EM, more accurate result can be captured, and it can be differentiated with other method. For example, by using the other method such as Dechow and Dichev (2002) to measure earnings quality can lead to a different result.

Lastly, it is also recommended that future research should consider other factors that may compromise the effectiveness of audit committee in performing their role on mitigating the EM activities. For examples, future research may consider the presence of inside directors and management of the company to compromise the audit committee members to perform their role effectively.

\section{Acknowledgement}

We would like to thank the Universiti Teknologi MARA (UiTM), in collaboration with the Ministry of Education Malaysia (MoE) in providing support for this research project. We are indeed grateful for the grant, without which we would not be able to carry out the research. We would also like to express our highest gratitude to everyone, directly or indirectly for helping us in our research.

\section{References}

Abbott, L. J., Parker, S., \& Peters, G. F. (2000). The effectiveness of Blue-Ribbon Committee recommendations in mitigating financial misstatements: An empirical study. 
Abbott, L. J., Parker, S. \& Peters, G. F. (2004). Audit committee characteristics and restatements. Auditing: A Journal of Practice \& Theory, 23(1), 69-87.

Agrawal, A., \& Chadha, S. (2005). Corporate governance and accounting scandals. Journal of Law \& Economics, 48(2), 371-406.

Al-Najjar, B. (2011). The determinants of audit committee independence and activity: Evidence from the UK. International Journal of Auditing, 15, 191-203.

Al-Sa'eed, A. M. (2011). Evaluation of the audit committee features and the manner in which they influence financial reporting: Evidence from Amman Stock Exchange. Proceeding of the conference on management, leadership, 10.

Al-Twaijry, M. A. A., Brierley, A. J., \& Gwilliam, R. D. (2002). An examination of the role of audit committees in the Saudi Arabian corporate sector, 10(4).

Alkdai, H., \& Hanefah, M. (2012). Audit committee characteristics and earnings management in Malaysian Sharia-compliant companies. Business and Management Review, 2(2), 52-61.

Baxter, P., \& Cotter, J. (2009). Audit committees and earnings quality. Accounting and Finance, 49, 265-290.

Beasley, M. S. (1996). An empirical analysis of the relation between the board of director composition and financial statement fraud. The Accounting Review, 71(4), 443-465.

Beasley, S. M., Carcello, V. J., \& Hermanson, R. D. (1999). Fraudulent financial reporting: 9871997 an analysis of U.S public companies.1-67.

Beasley, S. M., Carcella, V. J., Hermanson, R. D., \& Neal, L. T. (2009). The audit committee oversight process. Contemporary Accounting Research, 26(1), 65-122.

Bedard, J., Chtourou, M. S., \& Courteau, L. (2004). The effect of audit committee expertise, independence and activity on aggressive earnings management. Auditing: A Journal of Practice \& Theory, 23(2), 13-35.

BMLR. (2012). Listing Requirements of the Bursa Malaysia Stock Exchange. Bursa Malaysia Stock Exchange.

Bradbury, E. M., Mark, Y. T., \& Tan, S. M. (2006). Board characteristics, audit committee characteristics and abnormal accruals. Pacific Accounting Review, 18(2), 47-68.

Bronson, N. S., Carcello, V. J., Hollingsworth, W. C., \& Neal, L. T. (2009). Are fully independent audit committee really necessary? Journal of Accounting \& Public Policy, 28(4), 265280.

Claessens, S., \& Fan, H. P. J. (2002). Corporate governance in Asia: A survey. International Review of Finance, 3(2), 71-103.

Corporate Governance Blueprint. (2011). Towards Excellence in Corporate Governance. Securities Commission Malaysia.

Davidson, N. W., Biao, X., \& Weihong, X. (2004). Market reaction to voluntary announcements of audit committee appointments; The effect of financial expertise. Journal of Accounting \& Public Policy, 23(40, 279-293.

Davidson, R., Stewart, J., \& Kent, P. (2005). Internal governance structure and earnings management. Accounting and Finance, 45, 241-267.

Dechow, M. P., \& Dichev, D. I. (2002). The quality of accrual estimation errors. The Accounting Review, 77, 35-59.

Dechow, M. P., Sloan, G. R., \& Sweeney, P. A. (1995). Detecting earnings management. The Accounting review, 70(2), 193-225. 
Dechow, M. P., Sloan, G. R., \& Sweeney, P. A. (1996). Causes and consequences of earnings manipulation: An analysis of firm subject to enforcement actions by the SEC. Contemporary Accounting Research, 3(1), 1-36.

Defond, L. M., Hann, N. R., \& Hu, X. (2005). Does the market value financial expertise on audit committees of boards of directors? Journal of Accounting Research, 43(2), 153-192.

Fama, F. E. (1980). Agency problems and the theory of the firm. The Journal of Political Economy, 88(2), 288-307.

Felo, J. A., Krishnamurthy, S., \& Solieri, A. S. (2003). Audit committee characteristics and the perceived quality of financial reporting: An empirical analysis.1-39.

Haniffa, R., \& Cooke, T. (2000). Culture, corporate governance and disclosure in Malaysian listed companies. Journal of Business Finance \& Accounting, 33(7), 1034-1062.

Jamil, N. N., \& Nelson, P. S. (2011). An investigation on the audit committee effectiveness: The case for GLCs in Malaysia. Gadjah Mada International Journal of Business, 3(3), 287-305.

Jensen, C. M., \& Meckling, H. W. (1976). Theory of the firm: Managerial behavior, agency cost and ownership structure. Journal of Financial Economics, 3(4), 305-360.

Kim, J. H., \& Yoon, S. S. (2008). The impact of corporate governance on earnings management in Korea. Malaysian Accounting Review, 7(1), 43-59.

Klai, N., \& Omri, A. (2011). Corporate governance and financial reporting quality: The case of Tunisian firms. International Business Research, 4(1), 158-166.

Klein, A. (2002). Economic determinants of audit committee independence. The Accounting Review, 77(2), 435-452.

Lee, Y. H. (2008). The association between audit committee and board of director effectiveness and changes in the non-audit free ratio. Applied Financial Economics, 18,629-638.

Lee, Y. H., Mande, V., \& Ortman, R. (2004). The effect of audit committee and board of director independence on auditor resignation. 23(2), 31-146.

Lin, W. J., \& Hwang I. M. (2010). Audit quality, corporate governance, and earnings management: A meta-analysis. International Journal of Auditing, 14, 57-77.

Lin, W. J., Kang, G., \& Roline, A. (2009). The effects of the Blue-Ribbon Committee and the Sarbanes Oxley Act of 2002 on the characteristics of the audit committees and the board of directors. Advances in Accounting, Finance and Economics, 2(1), 1-11.

Liu, G., \& Sun, J. (2010). Director tenure and independent audit committee effectiveness. International Research Journal of Finance and Economics, (51),176-189.

Man, K. C. (2012). Corporate governance and earnings management: A survey of literature. 1-31.

MCCG Malaysian Code on Corporate Governance. (2007). Revised - 2007.Securities Commission, 2007.

MCCG Malaysian Code on Corporate Governance (2000). Finance Committee on Corporate Governance, 2000.

McMullen, A. D., \& Raghunandan, K. (1996). Enhancing audit committee effectiveness. Journal of Accountancy, 79-81.

Mohd Shatari, A. G. (2012). The dominance of directors, audit committee effectiveness and accounting conservatism: Malaysia Evidence. Unpublished PhD Thesis.

O'Reilly, A. C., \& Caldwell, F. D. (1981). The commitment and job tenure of new employees: Some evidence of post decisional justification. Administrative Science Quarterly,26, 566-597. 
Owen, R. J. (2004). Non- profit without audit committees: Risk disaster. Non-Profit World, 22(20, 24-25.

Owens-Jackson, A. L., Robinson, D., \& Shelton, W. S. (2009). The association between audit committee characteristics, the contracting process and fraudulent financial reporting. American Journal Business, 24(10, 57-65.

Quinones, A. M., Ford, K. J., \& Teachout, S. M. (1995). The relationship between work experience and job performance: A conceptual and meta-analytic review. Personnel Psychology, 48, 888-910.

Rahman, A. R., \& Ali, M, H, F. (2006). Board, audit committee, culture and earnings management: Malaysian Evidence. Managerial Auditing Journal, 21(7), 783-804.

Saleh, M. N., Iskandar, M. T., \& Rahmat, M. M. (2007). Audit committee characteristics and earnings management: Evidence from Malaysia. Asian Review of Accounting, 15(2), 147-163.

Sarbanes-Oxley Act. (2002). Corporate responsibility. Public Law, 107-204. Retrieved on 12 May 2012 from https://www.sec.gov/about/laws/soa2002.pdf

Schimidt, L. J., Hunter, E. J. Outerbrigde, N. A. (1986). Impact of job experience and ability on job knowledge, work sample performance, and supervisory ratings of job performance. Journal of Applied Psychology, 71(3), 432-439.

Sharma, V., Naiker, V., \& Lee, B. (2009). Determinants of audit committee meeting frequency: Evidence from a voluntary governance system. Accounting Horizons, 23(3), 245-263.

Sivaramakrishnan, K., \& Yu, C. S. (2008). On the association between corporate governance and earnings quality.1-36.

Tadesse, S. (2006). The economic value of regulated disclosure: Evidence from the banking sector. Journal of Accounting \& Public Policy, 25(1), 32-70.

Taylor, R. (1990). Interpretation of the correlation coefficient; A basic review. Journal of diagnostic Medical Solography, 1, 35-39.

Thoopsamut, W. \& Jaikengkit, O. A. (2009). Audit committee characteristics, audit firm size and quarterly earnings management in Thailand. 8(1), 3-12.

Vafeas, N. (2005). Audit committees, boards and the quality of reported earnings. Contemporary Accounting Research, 22(4), 1093-1122.

Vafeas, N. (2003). Length of board tenure and outside director independence. Journal of Business Finance \& Accounting, 30(7\&8), 1043-1064.

Xie, B., Davidson, N. W., \& Da Dalt, J. P. (2003). Earnings management and corporate governance: The role of the Board and the audit committee. Journal of Corporate Finance, 9(3), 295-317.

Yang, J. S., \& Krishnan, J. (2005). Audit committees and Quarterly earnings management. International Journal of Auditing, 9, 201-219.

Zhang, Y., Zhou, J., Zhou, N. (2006). Audit committee quality, auditor independence, and internal control weaknesses.1-37. 